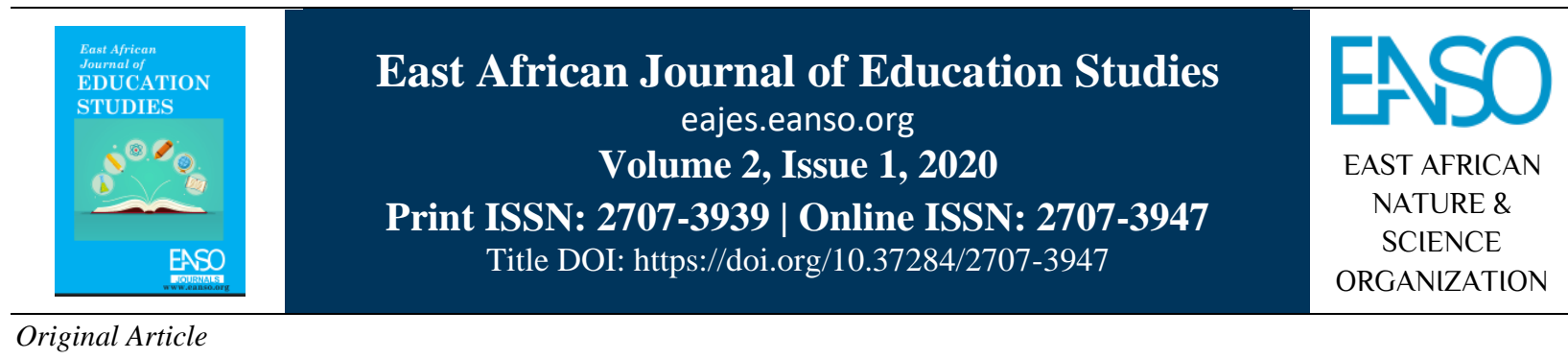

\title{
Pedagogical strategies and Motivation of Hospitality Management Learners in a Higher Education Institution in Botswana
}

\author{
Diketso Kelebemang Khutsafalo ${ }^{{ }^{*}}$ \& Prof Ushe Makambe, $P h D^{1}$ \\ ${ }^{1}$ Faculty of Hospitality and Sustainable Ecotourism, Botho University, P. O. Box 501564 Gaborone, Botswana. \\ ${ }^{2}$ Faculty of Business and Accounting, Botho University, P. O. Box 501564, Gaborone, Botswana; ORCID: \\ https://orcid.org/0000-0002-1936-5347; \\ *Author for Correspondence Email: Diketso.khutsafalo@bothouniversity.ac.bw.
}

Article DOI: https://doi.org/10.37284/eajes.2.1.257

\section{Date Published: ABSTRACT}

23 December 2020 The Botswana higher education system has been producing low-quality unemployable graduates and the low levels of learner motivation is believed to

Keywords: be a major factor. Premised on the Self-Determination Theory, the purpose of

Pedagogical Strategies,

Learner Motivation,

Self-Determination

Theory,

Hospitality Management,

Higher Education

Institution,

Botswana. motivation of hospitality management learners in a selected higher education institution in Botswana. A descriptive survey design was adopted while the quantitative methodology was employed. Descriptive and inferential statistics such as the mean, standard deviation, correlation and regression, which were products of the Statistical Package for Social Sciences (SPSS) software, were used to analyse data that was collected from 128 respondents who were selected from a population of 189 learners using stratified random sampling. This study provided empirical evidence on the influence of pedagogical strategies on learner motivation and will provide instructors with knowledge of pedagogical approaches that either facilitate or impede learner motivation. The findings of the study revealed a significant relationship between pedagogical strategies and learner motivation. However, it was discovered that certain pedagogical strategies employed by the instructors had a negative effect on learner motivation namely low quality of academic advising, not affording learners enough opportunities to do presentations in class and failure to effectively inculcate collaborative skills among learners. It is recommended that learners should be afforded opportunities for collaborative learning to stimulate peer engagement which facilitate motivation. The institution should ensure that the curriculum incorporates contemporary issues that are relevant to the learners, industry and society as this will instil in the learners a reason to want to learn with the assurance of ready employment after graduation. 


\section{APA CITATION}

Khutsafalo, D. K., \& Makambe, U. (2020). Pedagogical strategies and Motivation of Hospitality Management Learners in a Higher Education Institution in Botswana. East African Journal of Education Studies, 2(1), 197-210. https://doi.org/10.37284/eajes.2.1.257.

\section{CHICAGO CITATION}

Khutsafalo, Diketso Kelebemang, and Ushe Makambe. 2020. "Pedagogical strategies and Motivation of Hospitality Management Learners in a Higher Education Institution in Botswana”. East African Journal of Education Studies 2 (1), 197210. https://doi.org/10.37284/eajes.2.1.257.

\section{HARVARD CITATION}

Khutsafalo, D. K. and Makambe, U. (2020) "Pedagogical strategies and Motivation of Hospitality Management Learners in a Higher Education Institution in Botswana", East African Journal of Education Studies, 2(1), pp. 197-210. doi: 10.37284/eajes.2.1.257.

\section{IEEE CITATION}

D. K. Erukudi, and U. Makambe, "Pedagogical strategies and Motivation of Hospitality Management Learners in a Higher Education Institution in Botswana", EAJES, vol. 2, no. 1, pp. 197-210, Nov. 2020.

\section{MLA CITATION}

Khutsafalo, Diketso Kelebemang, and Ushe Makambe. "Pedagogical strategies and Motivation of Hospitality Management Learners in a Higher Education Institution in Botswana". East African Journal of Education Studies, Vol. 2, no. 1, Nov. 2020, pp. 197-210, doi:10.37284/eajes.2.1.257.

\section{INTRODUCTION}

Learner motivation is the learner's level of engagement in the process of learning which involves both intrinsic and extrinsic motivation (Knapper, 2017). Rizkalla and Seitz (2017) argue that it is critical to understand the motivation of students in order to retain them since learner retention has become a serious challenge for most higher education institutions, especially in the third world.

The hospitality and tourism sector in Botswana is bedevilled by challenges, particularly the small player, such as the mismatch between product quality and customer expectations emanating from an education system that is not as strong and as relevant as it should be. This education system has contributed to a hospitality sector that lacks the requisite skills especially at the higher management level both in-depth and breadth (Mahachi, 2014; Mahachi \& Shemi, 2014). These authors aver that given the central role played by the hospitality and tourism industry to the economic development of Botswana, it is therefore vitally important that there is a clear comprehension of what motivates hospitality management learners in higher education institutions in Botswana. Such knowledge will help curriculum designers and pedagogical experts to develop appropriate and effective pedagogical strategies that will culminate in the production of high quality and competent graduates who will take up middle and upper management positions in the hospitality sector and perform according to expectation.

The current education system in Botswana is such that learners attend school to complete grades but not to attain the skills and competencies that are required in a developing economy (Boikhutso and Molosiwa, 2019; Makwinja, 2017; Republic of Botswana, 2009). This could mean that teachers who would want to emphasise the importance of quality of teaching and learning may end up experiencing problems with learners who would look at these teachers as difficult and an impediment to learners' progression to the next grade and ultimately graduation. In private education institutions that operate as business models, learners are customers hence lecturers will be forced to dance to the tunes and whims of the learners resulting in them ending up toeing the line leading to the production of low-quality graduates.

The industry in Botswana has expressed concern about the type of graduates being churned out by higher education institutions. There has been lamentation about the failure of graduates to meet the needs of the industry due to a mismatch between the graduates produced by higher education institutions and industry needs (Botswana Training Authority, 2010; Siphambe, 2012). This scenario 
requires high levels of learner motivation to enhance the quality of the tertiary education output so that it matches the requirements of commerce and industry. This study was therefore necessary to establish if the pedagogical strategies employed by lecturers in the Faculty of Hospitality and Tourism in a selected higher education institution in Botswana were effective in motivating learners who were studying for a bachelor's degree in hospitality management to learn. The study is critical in identifying the shortcomings of the teaching and learning process that might have demotivated hospitality learners to learn more effectively given that these learners learn by doing.

\section{LITERATURE REVIEW}

Learners need motivation as it is an essential element in achieving quality education (Williams and Williams, 2011) and teachers should be the source of that motivation through the overall teaching process, especially content delivery (Weimer, 2018). For learners to transform their mindset and take their studies more seriously, teachers ought to use more effective pedagogical strategies and provide these learners with opportunities to think, to gather information through research and to engage more actively in the learning process (Weimer, 2018; Williams and Williams, 2011). Some pedagogical experts believe that effective classroom delivery strategies emanate from competent curriculum planning hence poor planning results in ineffective delivery of the curriculum thus contributing to decreased learner motivation (Nilsson, 2008; Yardimci, 2017). These authors opine that content delivery that is effective and well organised emerges from effective planning and this enhances learners' attraction and focus on the learning process. Such learners will always be stimulated to learn and will exhibit characteristics of strong organisation and preparedness to do well in their academic journey. It is therefore critical that learning institutions put in place effective plans for the design and implementation of effective pedagogical strategies that are interesting and pulsating which stimulate and motivate students to exude more enthusiasm for learning.

The most basic strategy that motivates learners in content delivery is the communication skills of the lecturer. Communication and teaching skills significantly influence the teacher's success or failure in his/her work (Derakhshan, Singh and Nazari, 2014; Quinn and Eckerson, 2010). The way teachers communicate with the learners can stimulate different behaviours in students and teachers who have good communication skills produce learners who are competent in communication thus partaking more effectively in class discussions and presentations. It is the lecturer's role to make the learning process more interesting by adapting teaching techniques that can motivate learners that include innovative and creative teaching approaches, commitment to the students, creating a conducive classroom learning environment and instilling a culture of practical learning (Quinn and Eckerson, 2010; Ullah, Sagheer, Sattar and Shahbaz, 2013). The $21^{\text {st }}$ century learning environment, unlike the traditional classroom setup of earlier times, requires innovative, interesting and challenging pedagogical strategies to satisfy the needs of an increasingly dynamic learner and workforce and if appropriate strategies are adopted, learners will be motivated to learn and their learning needs will be fulfilled.

Shousha's (2018) study established that learners of today can be motivated using technology (WhatsApp groups, internet exercises and mobile apps). This view is supported by other authors who concur that the use of technology in teaching increases learner engagement especially in conditions where the conventional lecture style is detested by learners (Cheong, Cheong and Filippou, 2013; Wang and Lieberoth, 2016). This implies that the ancient methods of curriculum delivery should be revisited and replaced by enhanced adoption and utilisation of the power of technology to make learning more scintillating and exciting. To enhance learner motivation, it is crucial to consider the use of pedagogical strategies that include effective classroom management, varying learner activities and rewarding learners. These are discussed below.

\section{Effective Class Management}

Various scholars have advocated for teachers to motivate learners through implementing effective class management techniques and utilising proper teaching methods (Derakhshan et al., 2014; Sattar, 2012). In affirmation of this, some authors postulate 
that teachers should engage learners in the learning process through student-centred learning activities, pay attention to learners' educational achievement, recognise top achievers and consider the educational needs of the learners in the learning process as means of taking full control of the learning situation (Jones, 2009; Sattar, 2012). These strategies involve the element of learner involvement thus giving learners an equal chance of participating in class, hence improving their motivation to learn and ultimately academic performance. In addition, other effective teaching strategies include class discussions, group work and cooperative learning methods (Anderson, 2007; Nilson, 2010; Ullah, et al., 2013).

Discussion forums in class are effective in the sense that they make teaching a two-way collaborative process and ensure that every opinion is valuable, whereas group work, on the other hand, enhances the communication skills and knowledge of the students. Nilson (2010) and Ullah et al. (2013) add that the cooperative learning method (working together to achieve shared goals in the form of small groups) should be adopted in teaching and learning as it encourages and motivates students to learn with the help of their peers. Though not mentioned too often, in Botswana, the cooperative learning method has been more evident in basic education unlike in tertiary institutions (Nilson, 2010). This strategy empowers learners to work collaboratively to come up with concrete solutions to problems thus fostering social cohesion in learners. However, it is important to note that group learning can only be valuable if the teacher is effective in group management to eradicate freeriders who do not effectively take part in group discussions but want to claim credit for group achievement. Such learners, if not identified by the teacher and assisted, will not benefit from the group learning process hence will not be motivated to learn and will subsequently lose interest in learning which symbolises a teacher's failure to rise to the top of the class.

\section{Varying Learner Activities}

An instructor who engages learners in learning activities that are varied and are of the learner's interest increases learners' intrinsic motivation (Moskovsky and Alrabai, 2009; Stroet, Opdenakker and Minnaert, 2013). This calls for instructors to monitor the reaction of the learners when teaching and adopt measures that best assist individual learners through a variety of learner activities that appeal to different categories of learners. If teachers could vary their methods of teaching, classroom activities would become more interesting which motivates learners to effectively participate in the learning process.

Demotivation of learners is normally triggered by how the instructor relays the curriculum to the students. Effective pedagogical approaches that exhibit variety motivate learners who, in turn, display enthusiasm to learn, positivity, curiosity and attentiveness while weak pedagogical strategies are known to demotivate learners who consequently become inactive, anxious, depressed and bored (Chapman, 2003; Keith, Pritchard and Roesch, 2006). Learners who are demotivated by the teacher's weak delivery strategies may end up losing interest in learning which may lead them to abandon the learning programme or even drop out of school altogether. Therefore, it is imperative for the instructor to focus on changing the negative attitudes and conduct of the learners to behaviours that indicate intrinsic motivation through interesting pedagogical approaches that exhibit variety and catch the attention of all learners all the time. Teachers should look out for traces of negative behaviour among learners and nip it in the bud before it becomes widespread and dominant. This can be done through even collaborating with learners and engage them in discussions and establishing appropriate teaching methods that students prefer thus involving learners in critical decision-making which leads them to feel ownership of the learning process boosting further their motivation and achievement.

One technique of varying learner approaches is alternating class revision with other pedagogical approaches which can be done as recaps at the end of every lesson or small tests or exercises at the end of the topic before the final end semester assessment. It is believed that learners value all forms of revision before writing final examinations and they enjoy learning when they experience examinations, where concepts covered, are familiar 
and when they have revised and received an effective evaluation and timely feedback (Anderson, 2007; Shousha, 2018). Revision, as a pedagogical tool, helps the learner to revisit the past content and tests the learners' understanding hence prepares the learners to do well in their ultimate assessments.

\section{Rewarding Learners}

In an effort to enhance their teaching strategies, some teachers inspire learners by offering external incentives which put learners under pressure to succeed (Jang, Reeve and Deci, 2010; Niemiec and Ryan 2009; Reeve and Jang 2006; Reeve, Deci and Ryan, 2004; Vansteenkiste, Niemiec and Soenens, 2010). However, the strategy of rewarding learners in education is controversial. Niemiec and Ryan (2009) argue that rewards should not only be based on academic achievement but, for students to be motivated, rewards should be aimed at influencing both academic results and change of behaviour. Rewards should not seek to foster academic excellence only but should stretch to acknowledging other areas where learners are doing well as it is a way of inspiring them. In support of this view, Keith et al (2006) believe that the tendency of encouraging competition among learners, through rewards/incentives, has the potential to weaken motivation for learning in a way that learners who do not perform well may feel unrecognised and may begin to view themselves as failures in life.

The above view is reinforced by Deci and Ryan (2000) who confirm that, under certain circumstances, extrinsic rewards could diminish intrinsic motivation hence in such circumstances, they should be avoided. The authors further contend that positive reinforcement through rewards that emphasise extrinsic motivation may be harmful to internal motivation and even divide learners which may destroy group cohesion during group activities as the anticipation of rewards turn learners into competitors rather than collaborators. To prevent such a negative occurrence among learners which has a detrimental effect on learning, rewards that lead to greater perceived self-determination or perceived competence increase intrinsic motivation and these should be adopted, for example, team incentives and verbal praises. Learner motivation may be enhanced by rewarding learners for anything positive during the performance of learning tasks no matter how small the positive aspect may seem, for example, praising a learner for completing a task, good handwriting/neatness, punctuality and paying attention.

\section{THEORETICAL FRAMEWORK}

The Self-Determination Theory (STD) provides the overarching theoretical framework to guide this study on how pedagogical strategies influence learner engagement and motivation focusing on the hospitality management students of a selected higher education institution in Botswana with particular emphasis on the student-teacher dialectical framework that is embedded within the SDT. The SDT comprises five mini theories that explain the motivational phenomena among learners as exhibited in Figure 1 below. 
Figure 1: Five mini theories of SDT and the motivational phenomena each was developed to explain

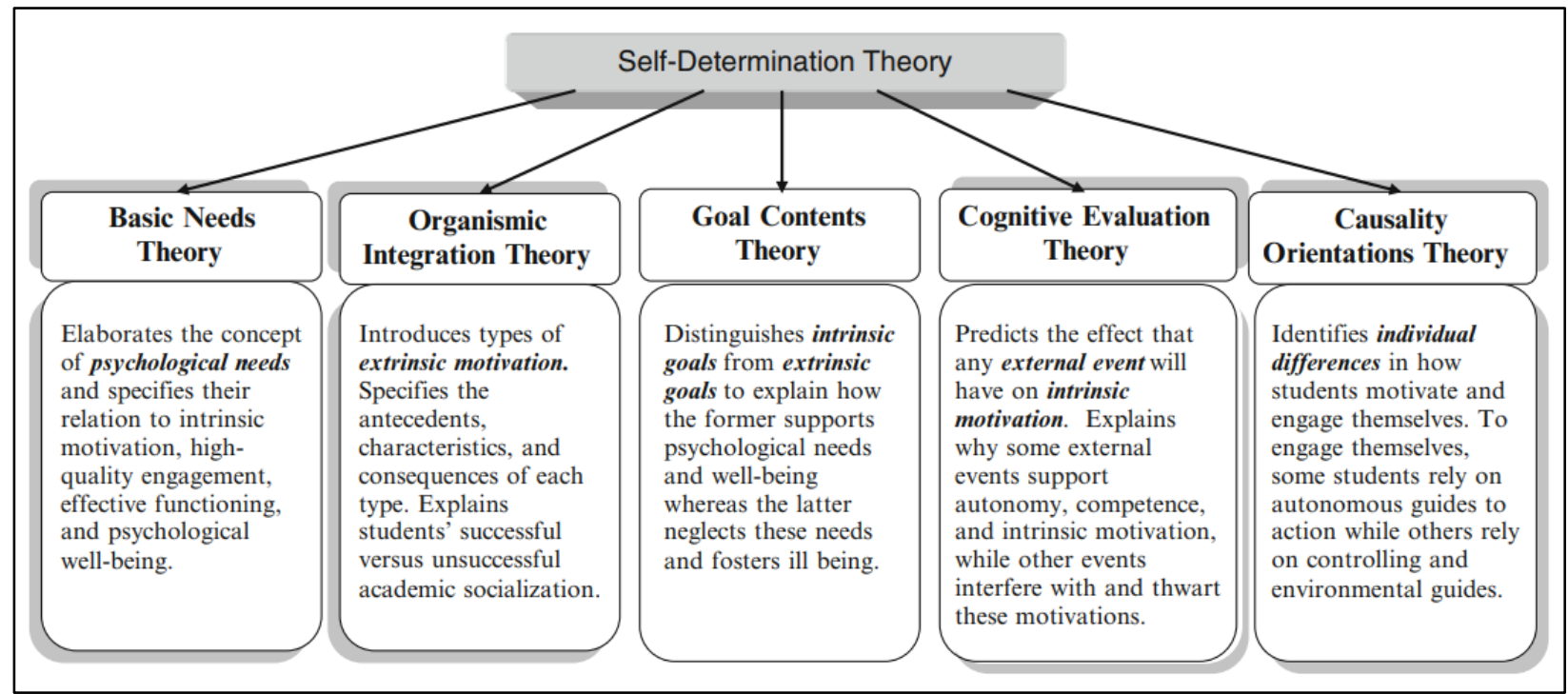

Source: (Deci and Ryan, 2000, p. 229)

The SDT assumes that all learners, irrespective of their age, gender, socioeconomic status or cultural background, hold inherent development inclinations such as intrinsic motivation, inquisitiveness and psychological desires that offer a motivational underpinning for high-quality classroom engagement and positive school functioning (Deci and Ryan, 2000; Reeve, et al., 2004; Ryan and Deci, 2002; Vansteenkiste, et al., 2010). Reeve and Halusic (2009) assert that the SDT places more emphasis on the instructional responsibility of revitalising learners' inner motivational assets as the crucial step in expediting high-quality learner engagement. Niemiec and Ryan (2009) aver that the SDT detects the inner motivational resources which all learners have and proffers suggestions on how teachers can involve, nurture, and vitalize these resources to create a flow of instruction that facilitates high-quality learner engagement which in turn stimulates learner motivation.

The SDT acknowledges that learners at times lack self-motivation, exhibit disaffection, and act in an irresponsible manner during the learning process because of low levels of motivation. So to address this apparent paradox of possessing inner motivational resources on the one hand yet demonstrating disaffection to learning on the other, the SDT identifies the classroom conditions that are created by the teacher in the form of pedagogical strategies that support and vitalize learners' inner motivational resources versus those that neglect, undermine, and thwart them (Deci and Ryan, 2000; Reeve, et al., 2004; Ryan and Deci, 2002). In doing so, the SDT addresses the interaction between learners' inner resources and the classroom conditions established by the teacher resulting in varying levels of learner engagement during the learning process. As such, the SDT becomes crucial in this study through its acknowledgement that effective pedagogical strategies play a scintillating role in creating classroom conditions that stimulate the learner's inner motivational resources resulting in enhanced motivation to learn hence effective learner participation in the learning process.

\section{MATERIALS AND METHODS}

This study adopted the positivist research paradigm resulting in the utilisation of the survey research design to collect and analyse data on the relationship between pedagogical strategies and motivation of hospitality management learners in a selected higher education institution in Botswana. The positivist philosophy was adopted because of its ability to effectively assist researchers in their quest to answer questions concerning relationships among well-defined concepts and these relationships can be expressed as measurable 
variables with the purpose of explaining, predicting and controlling phenomena with high degrees of certainty irrespective of the views of the observer (Cecez-Kecmanovic and Kennan, 2013; MolinaAzorin and Cameron, 2010).

The survey research design was applied to quantitatively describe specific aspects of the given population. This research design was chosen as it is believed to be the most suitable to the positivist paradigm since it is more closely related to the quantitative methodology which was adopted in this study (Howe, 2008; Ngulube, 2015). The positivist paradigm, the survey research design and the quantitative research methodology were used in this study to analyse the relationships between variables in a population namely the relationship between the pedagogical strategies used by instructors in the hospitality faculty and motivation of the learners hence the following hypothesis was tested:

$H_{1}$ : There is a significant and positive relationship between pedagogical strategies and motivation of hospitality management learners at the selected higher education institution.

In pursuance of the quantitative research methodology, data was collected using a self- administered structured questionnaire with both closed-ended and open-ended questions. The questionnaire was adopted as the data collection instrument as it is one of the most widely used and effective instruments for gathering survey data and can be administered in the absence of the researcher and is also straight-forward to analyse (Dawson, 2012). It was administered only after all the necessary research ethics issues had been addressed such as informed consent, assuring the respondents of the confidentiality of their responses and anonymity and their right to withdraw their participation from the study any time they chose to do so without any negative ramifications, and obtaining ethical clearance from the responsible authorities.

Data were collected from a population of 189 hospitality management students in the Faculty of Hospitality and Tourism from the first-year learners to the final year (fourth year). The research participants were selected using the simple random probability sampling technique to give every element of the population an identical likelihood of being chosen. The researcher adopted the stratified random sampling procedure to allow the learners at all levels (Year 1 to Year 4) to participate in the study in equal proportions as shown in Table 1 below.

Table 1: Population and sample strata

\begin{tabular}{lll}
\hline Level (Stratum) & $\begin{array}{l}\text { Population from each } \\
\text { stratum }\end{array}$ & $\begin{array}{l}\text { Sample size from } \\
\text { each stratum }\end{array}$ \\
\hline First-year class & 24 & 16 \\
Second-year class & 39 & 27 \\
Third-year class & 99 & 67 \\
Fourth-year class & 27 & 18 \\
Total population and total sample size & 189 & 128 \\
\hline
\end{tabular}

A sample of 128 respondents was selected from the population of all the four strata based on the Research Advisors (2006) sample size determination formula as shown in Table 1 above. The questionnaire adopted a 5-point Likert scale ranging from strongly agree to strongly disagree. The items on the Likert scale were assigned values as follows: Strongly Agree $(\mathrm{SA})=5$; Agree $(\mathrm{A})=$ 4; Neutral $(\mathrm{N})=3$; Disagree (D) $=2$ and Strongly Disagree $(\mathrm{SD})=1$. These were summarised using mean values and the Standard Deviation (SD). All the 128 questionnaires that were distributed were recovered and usable resulting in a $100 \%$ response rate which is quite commendable.

The study was tested for both reliability and validity. The validity of the study was established through factor analysis. To determine if factor analysis was suitable, the Kaiser-Meyer-Olkin (KMO) and Bartlett's Test of Sphericity (BTS) 
were employed. The KMO test was implemented to establish sampling adequacy to justify the use of factor analysis. The BTS helped to extract the maximum common variance for all items and to identify them with a common score or factor while the Average Variance Extracted (AVE) was used to measure the level of variance captured by a construct versus the level due to measurement error. Netemeyer, Bearden and Sharma (2003) suggest that a KMO correlation between 0.60 and 0.70 is considered acceptable for factor analysis and that the matrix should be significant at the value of ( $p<$ .05 ) and the BTS should be significant at $\alpha<.05$ to assume factorability of the correlation matrix, while the AVE of 0.5 is acceptable and above 0.7 is considered very good. The internal consistency reliability of the instrument was established through the Cronbach alpha reliability coefficient which stipulates that values from 0.6 are acceptable although the higher the values, the higher the reliability of the research instrument (Mugenda and Mugenda, 2003).

After receiving all the 128 completed questionnaires, the data was cleaned and analysed using the Statistical Package for Social Sciences (SPSS). Descriptive statistics (mean and SD) and inferential statistics (correlation and regression analysis) were used to analyse data. Correlation analysis was conducted to scrutinise the extent and level of association between the pedagogical strategies that the teachers were employing and learner motivation, while regression analysis was aimed at establishing the association and the strength of the association of these two variables (the dependent and the independent variables). In support of the use of the mean and SD in data analysis, Utts and Heckard (2007) aver that the mean is crucial in determining the overall trend of a data set as well as providing a quick snapshot of data, while the SD establishes if the data is spread more widely from the mean or aligns with the mean.

The use of correlation and regression analysis in this study was important as these statistical techniques enable the estimation of the relationships among variables and strength of these relationships, that is, the relationship between the dependent variable and one or more independent variables or predictors (Hancock, 2015). The author further postulates that the use of correlation and regression analysis assists one to understand how the typical value of the dependent variable changes while the independent variable is held constant and the strength of this change. In this study, correlation and regression analysis were used to exhibit how the value of learner motivation changed when the dependent variable (pedagogical strategies) was altered.

\section{DISCUSSION OF FINDINGS}

The internal consistency reliability of data was ascertained by the Cronbach's Alpha value of 0.647 which is above the universally agreed threshold of 0.6 (Mugenda and Mugenda, 2003) which implies that the research instrument that was used to collect data was reliable. To establish the validity of the constructs, the psychometric factor loadings, the KMO, the BTS and the Average Variance Extracted (AVE) were adopted. For the individual scale items, the study used the mean and the SD. These are displayed in Table 2 below.

Table 2: Psychometric properties of the contribution of pedagogical strategies to learner motivation

\begin{tabular}{|c|c|c|c|c|c|c|}
\hline Statements & KMO & $\begin{array}{l}\text { BTS's } \\
\text { test }\end{array}$ & Mean & SD & AVE & $\begin{array}{l}\text { Factor } \\
\text { Metrics }\end{array}$ \\
\hline & 0.72 & 97.951 & & & 82.426 & \\
\hline $\begin{array}{l}\text { Assessments have challenged me to do my best in my } \\
\text { academic work. }\end{array}$ & & & 4.13 & 0.68 & & 0.969 \\
\hline $\begin{array}{l}\text { The curriculum in my programme is relevant to the } \\
\text { industry's needs. }\end{array}$ & & & 2.99 & 0.70 & & 0.988 \\
\hline I work with other students outside the class on projects. & & & 3.85 & 0.60 & & 0.960 \\
\hline $\begin{array}{l}\text { I do not come to class without completing homework/ } \\
\text { assignments which will be needed for that class. }\end{array}$ & & & 4.00 & 0.77 & & 0.958 \\
\hline $\begin{array}{l}\text { The methods used by teachers encourage learners to form } \\
\text { study groups. }\end{array}$ & & & 2.92 & 0.92 & & 0.987 \\
\hline
\end{tabular}


East African Journal of Education Studies, Volume 2, Issue 1, 2020

Article DOI: https://doi.org/10.37284/eajes.2.1.238

\begin{tabular}{|c|c|c|c|c|}
\hline Statements & $\begin{array}{ll}\text { KMO } & \begin{array}{l}\text { BTS's } \\
\text { test }\end{array} \\
\end{array}$ & Mean & SD AVE & $\begin{array}{l}\text { Factor } \\
\text { Metrics }\end{array}$ \\
\hline $\begin{array}{l}\text { The curriculum at BU incorporates research (creating } \\
\text { knowledge). }\end{array}$ & & 3.84 & 1.38 & 0.978 \\
\hline $\begin{array}{l}\text { The modules delivered in my programme challenge my } \\
\text { thinking capacity. }\end{array}$ & & 2.92 & 0.72 & 0.977 \\
\hline Students are given a chance to ask questions in class. & & 4.09 & 0.29 & 0.983 \\
\hline I contribute to class discussions. & & 4.07 & 0.65 & 0.918 \\
\hline $\begin{array}{l}\text { I am given the opportunity to make class presentations } \\
\text { regularly. }\end{array}$ & & 2.89 & 0.66 & 0.899 \\
\hline $\begin{array}{l}\text { I regularly use technology in my learning (chat group, } \\
\text { emails, and blackboard) for discussions and submissions } \\
\text { of assignments. }\end{array}$ & & 4.43 & 0.50 & 0.997 \\
\hline $\begin{array}{l}\text { The quality of academic advising addresses my needs as } \\
\text { a learner. }\end{array}$ & & 2.85 & 0.57 & 0.940 \\
\hline
\end{tabular}

Table 2 above shows the twelve-factor loadings of the pedagogical strategies that contributed to student motivation at the selected higher education institution. The KMO is 0.72 which confirms the high validity of the study. The effects of pedagogical strategies account for $82.426 \%$ (AVE) in explaining the motivation of hospitality management learners at the institution. The factor loadings range from 0.899 to 0.997 with an average of 0.965. As per the factor metrics, the implementation of the use of technology in the syllabus appears to be a dominant response with a factor loading of 0.997. The AVE value of 0.8 , as a measure of the level of variance captured by the construct versus the level due to measurement error, is above 0.7 , a value generally considered as very good, whereas the AVE value at the level of 0.5 is acceptable (Netemeyer et al., 2003).

The results in Table 2 reveal that the use of technology was dominant in learner motivation $(M$ $=4.43$ ). This finding implies that the respondents embraced the use of technology to improve the learning experience. This finding is supported by Shousha (2018) who believes that learners are mostly motivated with a delivery strategy that encompasses the use of technology (Blackboard, WhatsApp groups, internet exercises and mobile apps). The more the learners have an interest in a concept with access to technology, the more their level of motivation in learning that concept will be.

The respondents believed that assessments were challenging them to do their best in their academic work $(M=4.13)$ and they were prepared for their classes as depicted by the completion of assignments and homework before classes began $(M=4.00)$. The results revealed that modules that were being delivered in the programme challenged learners' cognitive capacity $(M=4.21)$; teachers were giving learners a chance to ask questions $(M$ $=4.09)$ and class discussions were encouraged $(M$ $=4.07$ ). This shows that students were likely to derive motivation from these aspects since they entail strong learner engagement as suggested by previous studies. For example, Ullah et al. (2013) suggest that creating a competitive environment would motivate learners while group work enhances their communication skills. Sattar (2012) suggests that teachers should include discussions and increase students' engagement. These views have been supported in this study.

On the other hand, the results in Table 2 reveal that the respondents were concerned about the relevancy of the curriculum in relation to market needs $(M=2.99)$ and the low-quality academic advising $(M=2.85)$. In addition, the respondents believed that the teaching methods adopted by the teachers did not encourage learners to establish study groups $(M=2.92)$ and that the modules that were being delivered did not challenge the learners' intellectual capacity $(M=2.92)$. The respondents were concerned by the lack of opportunities for the learners to make presentations in class $(M=2.89)$. These deficiencies in pedagogical strategy generally result in decreased learner motivation which means they could have, likewise, demotivated hospitality learners in the selected higher education institution. Such deficiencies in pedagogy might have meant that learners were not challenged enough to search for knowledge due to 
weak pedagogical skills used by the teachers. Furthermore, the failure by the teachers at the selected higher education institution to encourage presentations in class and group participation may have resulted in a lack of learner autonomy (Shousha, 2018).

Furthermore, the findings from the open-ended questions are consistent with those discussed above. The findings revealed that the respondents were of the view that teaching could be improved by the use of visual aids in classroom delivery, provision of more revision opportunities, having more practical lessons, recognising top achievers, encouraging more independent study after class, giving timely academic feedback, introducing semester breaks to avoid learner burnout, having one on one lecturer-learner meetings, providing more industry-related discussions and having class competitions (debates, presentations). That these were coming from the respondents as proposals to enhance the variety and effectiveness of pedagogical strategies employed by their teachers may mean that the teachers of the selected institution were not using these teaching strategies or were not using them effectively. These findings confirm the assertion of the SDT which presupposes that all learners desire a learning environment that motivates them to learn through high-quality classroom engagement and positive school functioning.

A correlation analysis was conducted to establish the association between pedagogical strategies and learner motivation at the higher education institution covered in this study using a 2-tailed Pearson correlation test. The results are shown in Table 3 below.

Table 3: Correlation between pedagogical strategies and learner motivation

\begin{tabular}{llll}
\hline Correlations & & MHPTT & PEDST \\
\hline MHPTT & Pearson Correlation & 1 & $.648^{* *}$ \\
& Sig. (2-tailed) & & .000 \\
& $\mathrm{~N}$ & 128 & 128 \\
\hline PEDST & Pearson Correlation & $.648^{* *}$ & 1 \\
& Sig. (2-tailed) & .000 & 128 \\
& $\mathrm{~N}$ & 128 & \\
\hline **. Correlation is significant at the 0.01 level (2-tailed). &
\end{tabular}

\section{Key}

MHPTT - Learner motivation

PEDST - Pedagogical strategies

The findings in Table 3 above show that there is a significant correlation between pedagogical strategies and learner motivation $(r=0.648, p<$ $0.01)$. This means that the two variables are moving in the same direction. In other words, learner motivation increases as pedagogical strategies improve. This is supported by previous studies (Moskovsky and Alrabai, 2009; Shousha, 2018; Ullah, et al., 2013) which suggest that using the right pedagogical approaches results in high learner motivation which is the desire of the learner as confirmed by the SDT.

In addition, a regression analysis was carried out to evaluate the extent of the contribution of pedagogical strategies to learner motivation. The results are indicated in Table 4 below. 


\section{Table 4: Regression analysis: The contribution of pedagogical strategies to learner motivation}

\begin{tabular}{|c|c|c|c|c|c|c|c|c|c|c|c|c|c|}
\hline \multicolumn{14}{|c|}{ Coefficients $^{\mathrm{a}}$} \\
\hline \multirow[t]{2}{*}{ Model } & \multicolumn{3}{|c|}{ Unstandardized Coefficients } & \multirow{2}{*}{$\begin{array}{l}\begin{array}{l}\text { Standardized } \\
\text { Coefficients }\end{array} \\
\text { Beta }\end{array}$} & \multirow[t]{2}{*}{$\mathbf{t}$} & \multirow[t]{2}{*}{ Sig. } & \multicolumn{2}{|c|}{$\begin{array}{l}95.0 \% \text { Confidence } \\
\text { Interval for B }\end{array}$} & \multicolumn{3}{|c|}{ Correlations } & \multicolumn{2}{|c|}{$\begin{array}{l}\text { Collinearity } \\
\text { Statistics }\end{array}$} \\
\hline & $\mathbf{B}$ & & Error & & & & $\begin{array}{l}\text { Lower } \\
\text { Bound }\end{array}$ & $\begin{array}{l}\text { Upper } \\
\text { Bound }\end{array}$ & $\begin{array}{l}\text { Zero- } \\
\text { order }\end{array}$ & Partial & Part & Tolerance & VIF \\
\hline \multirow[t]{2}{*}{1} & (Constant) & -8.466 & 3.661 & & $-\overline{2} .312$ & .022 & -15.713 & -1.219 & & & & & \\
\hline & PEDST & .704 & .075 & .352 & 9.365 & .000 & .556 & .853 & .648 & .644 & .319 & .826 & 1.211 \\
\hline
\end{tabular}

The findings in Table 4 above reveal that pedagogical strategies have a positive and significant contribution to learner motivation. This is indicated by the standardised coefficients of the stepwise regression $(\beta=$ $0.352, \mathrm{t}=9.365, p<0.01$ ). Thus, a rise in the pedagogical skills of teachers by 10 units will result in an increase in learner motivation by 7.04 units. Thus, the hypothesis: 'There is a significant and positive relationship between pedagogical strategies and motivation of hospitality management learners at the selected higher education institution' is supported in this study and the multicollinearity assumptions have not been violated; the VIF is greater than 1 (1.211) and the tolerance value is less than $1(0.826)$. The deduction, therefore, is that pedagogical strategies are significantly and positively related to learner motivation. This finding is supported by the SDT which concurs that learners have inherent motivational resources and that teachers should use appropriate pedagogical strategies that nurture and energise these resources to establish a stream of classroom delivery which stimulates high-quality learner engagement which in turn stimulates learner motivation.

\section{CONCLUSION}

This study sought to explicate the role played by instructors' pedagogical strategies in facilitating learner motivation at a selected higher education institution in Botswana focusing on hospitality management students. The findings of the study revealed that some pedagogical strategies employed by the instructors had a negative effect on learner motivation. These included low quality of academic advising, not affording learners enough opportunities to do presentations in class, failure to effectively inculcate collaborative skills among learners and failure to deliver a curriculum that produced graduates who would meet industry needs. However, other aspects of pedagogical strategies were discovered to have a positive impact on learner motivation. These included the teachers' ability to challenge the students to apply themselves in their learning, encouraging learners to prepare for the next class, offering modules that stretched the students' intellectual capacity, incorporating research in curriculum delivery, and use of technology in teaching. 
The study established that an improvement in pedagogical strategies utilised by the teachers would result in a substantial increase in learner motivation and this variable was a robust factor in explaining the level of motivation of the hospitality students at the higher education institution covered in this study. This led to the acceptance of the stated hypothesis: There is a significant and positive relationship between pedagogical strategies and motivation of hospitality management learners at the selected higher education institution. It is therefore critical that hospitality management teachers of the selected higher education institution to conduct more research to identify instructional strategies that stimulate further enthusiasm among learners especially those that involve practical application to prepare learners for immediate employment upon graduation.

This study will contribute to the body of knowledge on learner motivation by providing empirical evidence on how pedagogical strategies can influence student motivation especially in private higher education institutions which are often bedevilled by inadequate learning resources emanating from the absence of government funding. The findings will provide teachers with the requisite knowledge to make informed decisions on the design, development and delivery of the appropriate curriculum that stimulate learner motivation in particular circumstances. This study will inform new teaching and learning approaches that will enable more effective learner engagement thereby improving the quality of teaching and learning. In a nutshell, this study will support teachers in their adoption of more effective teaching strategies that include the student-centred learning strategy where the learners play a more active and leading role in the learning process rather than being passive recipients of information as is the case with the teacher-centred instructional strategy.

The study has implications for future research. The scope of the study could be extended by examining the effect of various pedagogical strategies on learner motivation and academic achievement in public higher education institutions whose context differs significantly from that of private higher education institutions. Motivation of students can be affected by financial, family, student characteristics and social factors. Further study on these variables will be crucial in filling up gaps left by this study by examining how these variables will influence learner motivation in different types of higher education institutions in Botswana and the region.

This study adopted the quantitative research methodology which may not have adequately explored the attributes of the relationships among variables. Future researchers may consider exploiting other methodological approaches such as qualitative methodology or a combination of quantitative and qualitative research approaches (mixed methods) culminating in the triangulation of research findings which enhances the validity of the study.

\section{REFERENCES}

Anderson, K. M. (2007). Differentiating instruction to include all students. Preventing School Failure, 51(3), 49-54

Boikhutso, K. \& Molosiwa, M. (2019). Improving quality education in Botswana schools: An 'illusion' and 'elusive' pursuit. Journal of the Botswana Educational Research, 22(1), 1-15.

Botswana Training Authority. (2010). Tracer study on the employment outcomes of vocational training graduates. Botswana Training Authority. Available at http://www.bota.org.bw/sites

Cecez-Kecmanovic, D. \& Kennan, M.A. (2013). The methodological landscape: Information systems and knowledge management. In Williamson, K. and Johanson, G. (eds.), Research methods: Information, systems and contexts. Prahran, Victoria: Tilde Publishing

Cheong, C., Cheong, F. \& Filippou, J. (2013). Quick Quiz: A Gamified Approach for Enhancing Learning. Jeju Island: AISeL

Dawson, C. (2012). Practical research methods: A user-friendly guide to mastering research techniques and projects. Oxford: How to Books Ltd 
Deci, E. L. \& Ryan, R. M. (2000). The "what" and "why" of goal pursuits: Human needs and the self-determination of behavior. Psychological Inquiry, 11, 227-268

Derakhshan, M., Singh, D. \& Nazari, M. (2014). The contributions of library and information science education to the development of competencies in determining information needs: An Iranian case study. International Journal of Libraries and Information Services, 64(2), 144154

Hancock, G. (2015). Fortune cookies, measurement error and experimental design. Journal of Modern Applied Statistical Methods, 2(2), 293305

Howe, K. (2008). Against the QuantitativeQualitative incompatibility thesis (or Dogmas Die Hard). Educational Researcher, 17(8), 1016

Jang, H., Reeve, J. \& Deci, E. L. (2010). Engaging students in learning activities: it is not autonomy support or structure but autonomy support and structure. J. Educ. Psychol, 102, 588-600

Jones, M. (2009). Transformational Learners: Transformational Teachers. Australian Journal of Teacher Education, 34(2).

Keith, J., Pritchard, T. \& Roesch, B. (2006). Teaching strategies and student motivation. Potsdam: Newyork

Knapper, V. (2017). Factors that influence student academic motivation and how those factors impact the student achievement of third-grade students. Doctor of Education Thesis. Clark Atlanta University

Mahachi, D. (2014). Strategic framework for the promotion of local cuisine in Botswana. Unpublished Doctoral Thesis. Northwest University, Potchefstroom.

Mahachi, D. and Shemi, A.P. (2014). Students' experiences of the tourism and hospitality industrial attachment programmes: Lessons from the University of Botswana. Botswana Journal of Business, 7(1).
Makwinja, V.M. (2017). Rethinking education in Botswana: A need to overhaul the Botswana education system. Journal of International Education Research, 13(2), 45-58

Mugenda, O. M. \& Mugenda, A.G. (2003). Research methods: Quantitative and qualitative approaches. Nairobi: African Centre for Technology Studies

Netemeyer, R.G., Bearden, W.O. \& Sharma, S. (2003). Scaling procedures: Issues and applications. Thousand Oaks: Sage Publications

Molina-Azorin, J. M. \& Cameron, R. (2010). The application of mixed methods in organisational research: A literature review. The Electronic Journal of Business Research Methods, 8(2), 95-105

Moskovsky, C. \& Alrabai. F. (2009). Intrinsic motivation in Saudi learners of English as a foreign language. The Open Applied Linguistics Journal, 2: 1-10

Ngulube, P. (2015). Qualitative data analysis and interpretation: Systematic search for meaning. In Mathipa, E.R. \& Gumbo M.T. (eds), Addressing research challenges: Making headway for developing researchers. Noordywk: Mosala-MASEDI Publishers and Booksellers

Niemiec, C. P. \& Ryan, R. M. (2009). Autonomy, competence and relatedness in the classroom: Applying Self-Determination Theory to educational practice. Theory and Research in Education, 7(2), 133-144

Nilsson, P. (2008). Recognizing the needs -Student teachers learning to teach from teaching. Nordic Studies in Science Education (NordiNa), 4(1), 92-107

Nilson, L. B. (2010). Teaching at Its Best: A research-based resource for college instructors. San Francisco: Jossey-Bass

Quinn, T. \& Eckerson, T. (2010). Motivating students to read with collaborative reading quizzes. English Journal, 100(1), 89-91 
Reeve, J., Deci, E. L. \& Ryan, R. M. (2004). SelfDetermination Theory: A dialectical framework for understanding the sociocultural influences on student motivation. In McInerney, D. \& Van, S. Etten (Eds.). Research on sociocultural influences on motivation and learning: Big theories revisited. Greenwich, CT: Information Age

Reeve, J. \& Halusic, M. (2009). How K-12 teachers can put Self-Determination Theory principles into practice. Theory and Research in Education, 7, 145-154

Reeve, J. \& Jang, H. (2006). What teachers say and do to support students' autonomy during a learning activity. Journal of Educational Psychology, 98, 209-218

Ryan, R. M., \& Deci, E. L. (2002). An overview of Self-Determination Theory: An organismicdialectical perspective. In E. L. Deci \& R. M. Ryan (Eds.). Handbook of self-determination. Rochester, NY: University of Rochester Press

Republic of Botswana (2009, October). Botswana General Certificate of Secondary Education Evaluation Report. Department of Curriculum Development and Evaluation, Ministry of Education and Skills Development

Research Advisors. (2006). Sample size table. Available at http://researchadvisors.com//tools/SampleSize.htm

Sattar, T. (2012). Determinants and implications of weak teachers' performance in the education sector: A case of affiliated schools of Board of Intermediate and Secondary Education, Multan Division (Pakistan). International Journal of Accounting and Financial Reporting, 2(1), 116133

Shousha, A. (2018). Motivational strategies and student motivation in an EFL Saudi context. International Journal of English Language Education, 6(1), 20-44

Siphambe, H. (2012). The challenges of financing tertiary education in Africa: The case of Botswana. Paper presented at the TEC Conference, Botswana, 18 March
Stroet, K., Opdenakker, M.C. \& Minnaert, A. (2013). Effects of need supportive teaching on early adolescents' motivation and engagement: A review of the literature. Educational Research Review, 9, 65-87

Ullah, M.I., Sagheer, A., Sattar, T. \& Shahbaz, K. (2013). Factors influencing student motivation to learn in Bahauddin Zakariya University (Multan), Pakistan. International Journal of Human Resource Studies, 13(2), 91-108

Utts, J. M. \& Heckard, R. F. (2007). Mind on statistics. Belmont: Cengage Learning

Weimer, M. (2018). Deeper thinking about active learning. Faculty Focus. Available at https://www.facultyfocus.com/articles/teaching -professor-blog/deeper-thinking-activelearning/

Williams, K. C. \& Williams, C. C. (2011). Five key ingredients for improving student motivation. Research in Higher Education Journal, 11, 121123

Vansteenkiste, M., Niemiec, C. P. \& Soenens, B. (2010). The development of the five minitheories of Self-Determination Theory: A historical overview, emerging trends, and future directions. Advances in motivation and achievement: The decade ahead: Theoretical perspectives on motivation and achievement, 16(1), 105-167

Yardimci, F. (2017). A study on the relationship between the study process, motivation resources, and motivation problems of nursing students in different educational systems, Nurse Education Today, 48, 13-18 